\title{
PENGEMBANGAN MODEL PEMBELAJARAN BERBASIS KOOPERATIF
}

\author{
Randeska Manullang 1)*, M. Fitri Rahmadana ${ }^{2)}$, Aurora Elise Putriku ${ }^{3)}$ \\ 1) Fakultas Ekonomi, Universitas Negeri Medan \\ 2) Fakultas Ekonomi, Universitas Negeri Medan \\ 3) Fakultas Ekonomi, Universitas Negeri Medan \\ *Penulis korespondensi: randeskamanullang4504@gmail.com
}

\begin{abstract}
Pemahaman terhadap manajemen modal dalam perusahaan ini menjadi dasar bagi mahasiswa dalam mengatur perputaran modal kerja dalam suatu entitas bisnis, sehingga memberikan kemudahan bagi mahasiswa untuk diterima dalam dunia kerja. Saat ini kemampuan kognitif saja tidak begitu atau kurang berperan di dunia kerja. Orang yang pintar belum tentu mampu berkerja secara team selain itu belum tentu memiliki afektif dan keterampilan yang menunjang keberhasilan kerja team (Junaidi, 2009). Model pembelajaran kooperatif pada dasarnya memberikan ruang yang lebih luas kepada mahasiswa untuk bereksplorasi dan saling bekerjasama. Dengan pembelajaran kooperatif mahasiswa didorong bekerja sama secara maksimal. Kerjasama di sini adalah setiap anggota kelompok harus saling membantu menguasai bahan ajar. Bagi mahasiswa yang memiliki kemampuan tinggi harus membantu teman sekelompoknya yang memiliki kemampuan rendah, karena penilaian akhir ditentukan oleh keberhasilan kelompok. Penelitian ini dilakukan pada Universitas Negeri Medan. Pengumpulan data dilakukan dengan menggunakan observasi, wawancara, kuesioner dan documenter. Observasi dilakukan dengan melihat secara langsung proses belajar mengajar pada mata kuliah manajemen keuangan. Hasil penelitian menunjukkan bahwa model pembelajaran Manajemen keuangan yang dilakukan dosen pada konsepnya sudah menggunakan model pembelajaran kooperatif. Model Pembelajaran kooperatif yang diterapkan masih belum effektif terlihat dari hasil evaluasi mahasiswa yang masih rendah. Perlu adanya pengembangan model pembelajaran kooperatif yang sudah diterapkan pada bagian - bagian ; pembentukan kelompok diskusi, pemberian tugas dan kuis disetiap materi, pemberitahuan/pengumuman atas hasil tugas dan kuis serta memberikan hadiah bagi yang menjawab dengan benar dan tepat waktu, serta adanya penggunaaan lembar kegiatan mahasiswa. Rancangan Pengembangan model pembelajaran yang dirancang peneliti menggunakan pengembangan pada model pembelajaran Student Teams Achievement Division (STAD)
\end{abstract}

\section{Keywords: Model Pembelajaran Kooperatif, Kelompok Diskusi}




\section{PENDAHULUAN}

Dalam memberikan proses pembelajaran banyak masalah yang dialami dalam proses belajar untuk mencapai standar kompetensi tersebut. Pemahaman konsep belum sepenuhnya dicapai oleh mahasiswa, apalagi keahlian manejemen modal. Beberapa metode pembelajaran yang telah dilakukan, seperti penggunaan media presentasi, modul belajar, dan pemberian tugas individu ternyata belum menunjukkan hasil yang memuaskan .

Berdasarkan hasil observasi awal melalui wawancara dengan beberapa dosen pengampu mata kuliah Manajemen Keuangan di Program Studi Pendidikan Tata Niaga di Fakultas Ekonomi Universitas Negeri Medan menunjukkan beberapa masalah yang sering muncul, yaitu mahasiswa tidak dapat mengikuti pembelajaran dengan baik, mahasiswa tidak dapat mengerjakan tugas yang diberikan dosen, dan mahasiswa yang aktif hanya beberapa orang saja dalam aktivitas belajar. Selain itu karena ketidakmampuan mahasiswa dalam keahlian manajemen keuangan membuat banyaknya sarjana- sarjana alumni fakultas ekonomi Universitas Negeri medan khususnya jurusan Pendidikan Tata Niaga cukup lama mendapatkan pekerjaan.

Saat ini kemampuan kognitif saja tidak begitu atau kurang berperan di dunia kerja. Orang yang pintar belum tentu mampu berkerja secara team selain itu belum tentu memiliki afektif dan keterampilan yang menunjang keberhasilan kerja team. Junaidi (2009).

Berdasarkan kondisi tersebut maka dalam pembelajaran Manajemen Keuangan perlu adanya pengembangan metode pembelajaran yang menarik agar mahasiswa antusias dan tertarik untuk mempelajari dan memahami mata kuliah tersebut secara keseluruhannya. Metode pembelajaran yang menarik tentunya harus disertai dengan kemasan yang dapat meningkatkan motivasi dan kepercayaan diri mahasiswa dalam mempelajari mata kuliah Manajemen Keuangan. Dalam hal ini dosen dapat mencoba model belajar untuk mata kuliah manajemen keuangan dengan sistem berkelompok yaitu model pembelajaran kooperatif.

Menurut Trianto (2007:41) bahwa pembelajaran kooperatif muncul dari konsep bahwa peserta didikan lebih mudah menemukan dan memahami konsep yang sulit jika mereka saling berdiskusi dengan temannya.Wina
JURNAL NIAGAWAN Vol 6 No 2 Oktober 2017 Sanjaya (2010: 242) menyatakan pembelajaran kooperatif sebagai model pembelajaran dengan menggunakan sistem mengelompokkan atau tim kecil, yaitu antara empat sampai enam orang yang mempunyai latar belakang kemampuan akademik, jenis kelamin, ras, atau suku yang berbeda (heterogen).

Menurut Abdurrahman dan Bintaro (2000:78) bahwa pembelajaran kooperatif adalah pembelajaran yang secara sadar dan sistematis mengembangkan interaksi yang silih asah, silih asih dan silih asuh antara sesama siswa sebagai latihan hidup di dalam masyarakat nyata.

Model pembelajaran kooperatif pada dasarnya memberikan ruang yang lebih luas kepada mahasiswa untuk bereksplorasi dan saling bekerjasama. Dengan pembelajaran kooperatif mahasiswa didorong bekerja sama secara maksimal. Kerjasama di sini adalah setiap anggota kelompok harus saling membantu menguasai bahan ajar. Bagi mahasiswa yang memiliki kemampuan tinggi harus membantu teman sekelompoknya yang memiliki kemampuan rendah, karena penilaian akhir ditentukan oleh keberhasilan kelompok. Oleh sebab itu setiap anggota kelompok harus memiliki rasa tanggungjawab terhadap kelompoknya,Istiningrum dan Sukanti (2012).

\section{TINJAUAN PUSTAKA}

\section{Aktivitas Belajar}

Aktivitas belajar adalah aktivitas yang bersifat fisik, mental, intelektual, dan emosional untuk memperoleh hasil belajar yang berupa perpaduan antara kognitif, afektif, dan psikomotor. Menurut Oemar Hamalik (2011: 175-176) manfaat aktivitas belajar adalah siswa mampu mencari pengalaman sendiri dan langsung mengalami sendiri, siswa mampu berbuat sendiri dan akan mengembangkan seluruh aspek pribadinya, siswa mampu memupuk kerjsama yang harmonis di kalangan para siswa yang pada gilirannya dapat memperlancar kerja kelompok, siswa mampu belajar dan bekerja berdasarkan minat dan kemampuan sendiri, memupuk disiplin belajar dan suasana belajar yang demokratis dan kekeluargaan, musyawarah, serta mufakat, serta membina dan memupuk kerjasama antar sekolah dan masyarakat, dan hubungan antar guru dan orang tua siswa, yang bermanfaat dalam pendidikan, pembelajaran dan belajar dilaksanakan secara realistik dan konkrit, sehingga mengembangkan pemahaman dan 
berpikir kritis serta menghindarkan terjadinya verbalisme dan menjadi hidup sebagaimana halnya kehidupan dalam masyarakat yang penuh dinamika.

\section{Pembelajaran Kooperatif (Cooperative Learning)}

Smith dan MacGregor (1992) mendefinisikan cooperative learning sebagai "the most carefully structured end of the collaborative learning contiunuum" (Ravenscroft,1995). Johnson, Johnson dan Holubec (1994) mendefinisikan cooperative learning sebagai "the instructional use of small groups so that students work together to maximize their own and each other's learning" (Phipps et al., 2001).

Berbagai riset tentang cooperative learning menunjukkan hasil yang konsisten bahwa cooperative learning akan meningkatkan prestasi, hubungan interpersonal yang lebih positif dan self-esteem yang lebih tinggi dibanding upaya kompetitif atau individualistis (Phipps et al., 2001). Phipps et al. (2001) mencatat keberhasilan metode iniantara lain dari hasil riset Felder dan Brent (1996) yang menyatakan bahwa pendekatan ini meningkatkan motivasi untuk belajar, memori pengetahuan, kedalaman pemahaman dan apresiasi subyek yang diajar. Riset juga menunjukkan bahwa praktik cooperative learning mengarahkan mahasiswa pada pencapaian prestasi yang lebih tinggi, lebih efisien dan efektifnya proses dan pertukaran informasi, meningkatkan produktivitas, hubungan yang positif di antara mahasiswa, dan membentuk saling percaya antar teman, dibandingkan dengan pengalaman pembelajaran kompetitif dan/atau individualistis (Potthast, 1999).

\section{Jenis-jenis Pembelajaran Kooperatif}

\section{A. Student Teams Achievement Division (STAD).}

STAD dikembangkan oleh Robert Slavin dan teman-teman di Universitas John Hopkin, merupakan pendekatan Cooperatif Learning yang paling sederhana. STAD mengacu pada belajar kelompok, menyajikan informasi akademik baru pada siswa setiap minggu dengan menggunakan presentasi verbal dan teks.

- Mahasiswa dalam 1 kelas dibagi menjadi kelompok-kelompok dengan jumlah 4 atau 5 orang.
JURNAL NIAGAWAN Vol 6 No 2 Oktober 2017

- Setiap kelompok harus heterogen yaitu laki dan perempuan,bermacam suku dan kemampuan tinggi, sedang dan rendah.

- Anggota tim menggunakan lembar kegiatan untuk menuntaskan pelajarannya.

- Kemudian saling membantu sama lain untuk memahami pelajaran melalui tutorial, kuis dan melakukan diskusi.

- Setiap minggu atau 2 minggu siswa diberi kuis. Kuis diskor dan tiapindividu diberi skor perkembangan. Skor perkembangan tidak berdasarkan skor mutlak mahasiswa tetapi berdasarkan pada seberapa jauh skor itu melampaui rata-rata skor siswa yang lalu.

- Setiap minggu lembar penilaian diumumkan dengan skor tertinggi.

- Kadang-kadang seluruh tim yang mencapai kriteria tertentu dicantumkan dalam lembar tersebut.

\section{B. JIGSAW}

Jigsaw dikembangkan dan diuii coba

Elliot Aroson bersama teman-teman Universitas Texas, kemudian diadaptasikan oleh Slavin.

- Mahasiswa dibagi berkelompok dengan 5 atau 6 anggota kelompok belajar heterogen.

- Materi diberikan dalam bentuk teks.

- Setiap anggota bertanggung jawab untuk mempelajari bagian tertentu dari bahan yang diberikan. Misalnya: Mahasiswa akan mempelajari tentang penjurnalan, maka siswa secara berbeda mempelajari tentang nama-nama perkiraan,jenis-jenis jurnal, dan bentuk-bentuk jurnal.

- Anggota dari kelompok lain juga mempelajari hal yang sama. Kelompok tersebut kita sebut dengan kelompok ahli yaitu ahli nama-nama perkiraan, ahli jenis-jenis jurnal, dan ahli bentukbentuk jurnal.

- Selanjutnya anggota tim ahli kembali ke kelompok asal dan mengajarkan apa yang dipelajarinya dan didiskusikan dalam kelompok ahlinya untuk diajarkan pada temen sekelompoknya.

- Pertemuan dan diskusi kelompok asal, siswa dikenai kuis secara individual tentang materi belajar.

- Jigsaw versi Slavin, skor tim menggunakan prosedur skoring yang sama dengan STAD yaitu Tim dan individu yang mendapat skor tinggi 
mendapat pengakuan dalam lembar pengakuan mingguan.

\section{Investigasi Kelompok ( IK)}

Model ini merupakan model Cooperative Learning yang paling kompleks dan sulit diterapkan. Model ini dikembankan oleh Thelan dan dipertajam oleh Sharan.

- Pendekatan ini memerlukan norma dan struktur kelas yang rumit yaitu mengajar siswa ketrampilan komunikasi dan proses kelompok yang baik.

- Pengajar membagi kelompok dengan anggota 5 atau 6 yang heterogen.

- Untuk beberapa kasus, kelompok dibentuk dengan mempertimbangkan keakraban atau minat yang sama dalam topik tertentu.

- Selanjutnya mahasiswa memilih topik untuk diselidiki.

- Kemudian menyiapkan dan mempresentasikan laporannya pada seluruh kelas.

- Sharan dkk (1984) menetapkan 6 tahap IK yaitu:

1. Pemilihan Topik, Mahasiswa memilih topik yang biasanya sudah ditetapkan oleh pengajar, selanjutnya mahasiswa diorganisasi menjadi 2 s/d 6 anggota tiap kelompok menjadi kelompok yang berorientasi tugas dimana dalam kelompok hendaknya heterogen secara akademis maupun etnis.

2. Perencanaan

Kooperatif, Mahasiswa dan pengajar merencanakan prosedur pembelajaran dan tujuan khusu yang konsisten dengan topik yang dipilih.

3. Implementasi, Mahasiswa menerapkan rencana yang telah dikembangkan. Kegiatan hendaknya melibatkan ragam aktivitas dan ketrampilan yang luas dan juga mengarahkan mahasiswa pada jenis sumber belajar yang berbeda baik didalam maupun diluar kelas. Pengajar secara ketat mengikuti kemajuan tiap kelompok dan menawarkan bantuan bila diperlukan.

4. Analisis dan Sistesis, mahasiswa menganalisi dan mengevaluasi informasi dan merencanakan
JURNAL NIAGAWAN Vol 6 No 2 Oktober 2017 bagaimana informasi tersebut diringkat dan disajikan dengan menarik untuk dipresentasikan pada seluruh kelas.

5. Presentasi Hasil Final, semua kelompok mempresentasikan dengan menarik agar mahasiswa lain saling terlibat sehingga memperoleh perspektif yang lebih luas dan presentasi ini dikoordinasi oleh pengajar.

6. Evaluasi, Kelompok-kelompok menangi aspek yang berbeda dari topik yang sama, mahasiswa dan pengajar mengevaluasi tiap kontribusi kelompok terhadap kerja kelas. Evaluasi dalam bentuk individual dan kelompok..

\section{Pendekatan Struktural}

Pendekatan ini dikembangkan oleh Spencer Kagen dkk (1993), pendekatan ini memberi penekanan pada penggunaan struktur yang dirancang untuk mempengaruhi pola interaksi siswa. Kagen menghendaki siswa bekerja saling membantu dalam kelompok kecil dan lebih menekankan pada penghargaan kooperatif daripada individual. Ada struktur yang dikembangkan untuk meningkatkan perolehan isi akademik ada juga yang dirancang untuk mengajarkan ketrampilan sosial atau ketrampilan kelompok. Ada 2 macam struktur yang dikembangkan untuk mengajarkan isi akademik atau untuk men-cek pemahaman mahasiswa terhadap isi tertentu yaitu Thinkpair-share dan Numbered-head-togather, sedangkan untuk mengajarkan ketrampilan sosial yaitu Active Listening dan Time token:

\section{Think-pair-share}

Dikembangkan oleh Frank Lyman dkk dari Universitas Maryland (1985).

- Strategi ini menantang asumsi bahwa seluruh resitasi dan diskusi perlu dilakukan dalam seting seluruh kelompok.

- Prosedur ditetapkan secara eksplisit untuk memberi siswa waktu untuk banyak berfikir, menjawab dan saling membantu.

- Pengajar menginginkan siswa memikirkan secara mendalah tentang apa yang telah dialami.

- Langkah-langkahnya sebagai berikut:

Tahap: 1, Thinking (berfikir). Pengajar mengajukan pertanyaan, kemudian 
mahasiswa diminta untuk memikirkan pertanyaan tersebut secara mandiri untuk beberapa saat.

Tahap: 2, Pairing. Pengajar meminta mahasiswa untuk berpasangan dengan mahasiswa lain untuk mendiskusikan apa yang telah dipikirkan. Dalam tahap ini diharapkan berbagi jawaban. Biasanya pengajar memberi waktu 4 atau 5 menit untuk berpasangan.

Tahap: 3, Share. Pengajar meminta pada pasangan untuk berbagi seluruh kelas untuk berbagi dengan seluruh kelas tentang apa yang telah dibicarakan secara bergiliran untuk melaporkan.

\section{Numbered-head-together}

Dikembangkan oleh Spencer Kagen (1993) untuk melibatkan lebih banyak siswa dalam menelaah materi dan mencek pemahaman terhadap isi pelajaran. Langkah-langkahnya sebagai berikut:

Tahap: 1, Penomoran. Pengajar membagi mahasiswa dalam kelompok yang beranggota 3 -5 orang dan diberi nomor 1 sampai 5.

Tahap: 2, Mengajukan Pertanyaan. Pengajar mengajukan pertanyaan yang bervariasi pada mahasiswa. Pertanyaan dapat berbentuk pertanyaan atau arahan misalnya: Pastikanlah bahwa bumi tersebut bulat.

Tahap: 3, Berfikir Bersama. Mahasiswa menyatukan pendapat terhadap jawaban pertanyaan dan meyakinkan tiap anggota dalam timnya mengetahui jawaban tersebut.

Tahap: 4, Menjawab. Pengajar memanggil satu nomor tertentu, kemudian nomor yang disebut mahasiswa mengacungkan tangannya dan menjawab pertanyaan untuk seluruh kelas..

\section{METODE PENELITIAN}

\section{Tempat dan Waktu Penelitian}

Penelitian ini dilakukan pada Universitas Negeri Medan

\section{Desain dan Prosedur Penelitian}

Sejalan dengan tujuan yang ingin dicapai dalam penelitian ini, yakni penyusunan model pengembangan pembelajaran berbasis Kooperatif dan kemudian mengoptimalkan aplikasinya, maka penelitian ini menggunakan metode Research and Development (R\&D), dimulai dari kegiatan survey pendahuluan dan perancangan model, uji coba model, sosialisasi dan implementasi. Penelitian ini akan dibagi
JURNAL NIAGAWAN Vol 6 No 2 Oktober 2017 dalam tiga tahapan pelaksanaan kegiatan sebagai berikut :

a. Tahap I

Merupakan tahap persiapan, kegiatannya adalah Review literature, melakukan survey pendahuluan dengan melihat proses belajar mengajar manajemen keuangan yang dilakukan dan menyebarkan kuesioner kepada dosen dan mahasiswa tentang mata kuliah manajemen keuangan.

b. Tahap II

Ditahap ini, Rancangan model pembelajaran akan di uji coba dengan review ahli, uji coba satu satu dan uji coba kelompok kecil dalam mata kuliah manajemen keuangan dan akan dilakukan survey lanjutan untuk mengetahui sejauhmana manfaat model pembelajaran tersebut dalam meningkatkan kompetensi mahasiswa. Dari hasil survey tersebut diharapkan berbagai tanggapan dan masukan untuk penyempurnaan model pembelajaran kooperatif dalam bentuk modul.

c. Tahap III

Pada tahap ini model pembelajaran yang telah dihasilkan disosialisasikan dan diimplementasikan kepada para dosen dosen mata kuliah manajemen keuangan melalui pelatihan pelatihan ke dosen mata kuliah manajemen keuangandan akan di evaluasi.

\section{Teknik Pengumpulan Data}

Pengumpulan data dilakukan dengan menggunakan observasi, wawancara, kuesioner dan documenter. Observasi dilakukan dengan melihat secara langsung proses belajar mengajar pada mata kuliah manajemen keuangan. Wawancara dilakukan untuk mengumpulkan data data berupa informasi tentang permasalahan yang dihadapi mahasiswa untuk memahami konsep manajemen modal.Kemudian kuesioner dirancang untuk mendapatkan informasi sebanyak banyaknya tentang mahasiswa dan dosen yang mengampu mata kuliah tersebut. Sedangkan studi documenter dilakukan untuk mendapatkan model model pembelajaran berbasis kooperatif yang sesuai untuk mata kuliah manajemen keuangan untuk bahan perbandingan dan pengembangan model pembelajaran yang akan dikembangkan

\section{HASIL DAN PEMBAHASAN}

Pembelajaran yang menarik sangat diperlukan dalam proses belajar mengajar agar mahasiswa antusias dan tertarik untuk 
mempelajari dan memahami mata kuliah tersebut secara keseluruhannya. Metode pembelajaran yang menarik tentunya harus disertai dengan kemasan yang dapat meningkatkan motivasi dan kepercayaan diri mahasiswa dalam mempelajari mata kuliah manajemen keuangan.Dalam hal ini dosen dapat mencoba model belajar Manajemen keuangan dengan sistem berkelompok yaitu model pembelajaran kooperatif.Model pembelajaran kooperatif pada dasarnya memberikan ruang yang lebih luas kepada mahasiswa untuk bereksplorasi dan saling bekerjasama. Dengan pembelajaran kooperatif mahasiswa didorong bekerja sama secara maksimal. Kerjasama di sini adalah setiap anggota kelompok harus saling membantu menguasai bahan ajar.Bagi mahasiswa yang yang memiliki kemampuan tinggi harus membantu teman sekelompoknya yang memiliki kemampuan rendah, karena penilaian akhir ditentukan oleh keberhasilan kelompok.

Survey dilakukan dengan menyebarkan kuesioner kepada responden terdiri dari mahasiswa dan dosen. Adapun kuesioner yang diberikan berisi pertanyaan tentang dua hal yaitu ; pertama kondisi pembelajaran kooperatif yang dilakukan selama ini dan kedua model pembelajaran kooperatif yang diharapkan kedepan.

Dari hasil survey pendahuluan yang sudah dilakukan maka dapat diketahui bahwa pertama kondisi pembelajaran kooperatif yang dilakukan selama ini pada mata kuliah manajemen keuangan ternyata sudah menggunakan model pembelajaran kooperatif namun belum effektif.Hal ini tercermin dari hasil jawaban responden baik mahasiswa maupun dosen yang rata - rata setuju bahkan sangat setuju dengan pernyataan tentang ; adanya review materi kuliah sebelumnya diawal pertemuan, adanya pertanyaan dari mahasiswa bila kurang jelas, dosen menjelaskan setiap materi ajar, dosen mengkaitkan antara materi ajar dengan lingkungan hidup, dalam proses pembelajaran dosen menggunakan media pembelajaran, adanya interaksi antara dosen dengan mahasiswa melalui media belajar, adanya pemberian nilai setiap materi ajar, adanya dorongan kepada mahasiswa untuk bertanya, berfikir dan berdiskusi.

Selain itu pernyataan lain yang dinyatakan setuju dan sangat setuju oleh responden adalah tentang dalam proses
JURNAL NIAGAWAN Vol 6 No 2 Oktober 2017 pembelajaran mahasiswa dan dosen aktif dalam bertanya dan menjawab materi materi ajar yang dibahas, diakhir perkuliahan dosen selalu melakukan penguatan, review dan kesimpulan atas materi ajar yang disajikan, terakhir dosen selalu melakukan evaluasi melalui tes untuk melihat hasil belajar mahasiswa.

Dari pernyatatan - pernyataan diatas peneliti dapat simpulkan bahwa model pembelajaran manajemen keuangan yang ada selama ini masih bertumpu pada satu arah, dimana dosen masih sebagai nara sumber utama dalam proses pembelajaran. Walaupun dosen dan sebahagian mahasiswa sudah aktif dalam proses belajar mengajar tersebut. Namun mahasiswa aktif dalam bertanya dan memberikan jawaban ketika dosen aktif juga dalam memberikan pertanyaan dan jawaban.Akhirnya ketika ada tugas atau pertanyaan yang dapat dijawab oleh mahsiswa hanya beberpa dosen saja yang memberikan hadiah.Hal ini terlihat dari jawaban responden yang lebih banyak menyatakan tidak setuju dengan adanya pemberian hadiah ketika mahasiswa dapat menyelesaikan tugas dengan baik dan benar.Dengan demikian mahasiswa kurang termotivasi dalam menyelesaikan tugas dikelas dengan baik dan tepat waktu.

Kedua, hasil survey pendahuluan menunjukkan bahwa model pembelajaran kooperatif yang diharapkan responden (mahasiswa dan dosen) kedepannya adalah agar tidak lagi dosen yang menjadi nara sumber utama tetapi mahasiswa juga dapat terlibat dalam dan mampu menjadi nara sumber dalam pembelajaran. Hal ini terlihat dari hasil jawaban responden yang memberikan pernyataan pernyataan setuju sampai sangat setuju tentang bila dilakukannya hal - hal sebagai berikut : pembahasan materi dilakukan melalui diskusi secara kelompok, pembagian kelompok dilakukan oleh dosen, kelompok diskusi harus dari mahasiswa yang berbeda (dalam hal tingkat pemahamannya, jenis kelamin), adanya lembar kegiatan dalam menuntaskan materi yang diberikan, adanya pertanyaan/kuis atas tugas yang diberikan dan hasilnya diumumkan. Meningkatnya pemikiran kritis mahasiswa dengan proses pembelajaran berkelompok. Mahasiswa lebih aktif dalam mencari sumber sumber pembelajaran dan terakhir komunikasi dan interaksi atar mahasiswa dan dosen dapat dilakukan dengan baik. 
Berdasarkan hasil jawaban responden ini maka peneliti menyimpulkan bahwa dari proses belajar mengajar yang ada selama ini dalam mata kuliah manajemen keuangan perlu adanya pengembangan atas model pembelajaran kooperatif yang sudah dilakukan. Hal ini dimaksudkan agar proses belajar mengajar dapat bersumber dari dua arah dan dengan adanya kelompok - kelompok diskusi ini diharapkan mahsiswa akan dapat lebih aktif dalam mencari sumber-sumber materi ajar yang diberikan. Jadi tidak hanya mengharapkan dari satu nara sumber saja yaitu dosen.

Namun dalam menetapkan kelompok diskusi mahasiswa masih tidak bersedia jika mereka ditempatkan pada kelompok manasaja.Artinya kelompok diskusi juga tidak harus ditentukan oleh dosen sendiri tetapi juga harus melibatkan mahasiswa.Agar diskusi kelompok dapat berjalan dengan baik. Kedepannya ini akan berdampak pada peningkatan kompetensi mahasiswa dalam bidang manajemen keuangan dan akhirnya nanti diharapkan dapat meningkatkan daya saing mereka didunia kerja. Sebagaimana hasil penelitian yang sudah dilakukan oleh Ravenscroft et al. (1995) menemukan penggunaan metode pembelajaran kooperatif akan meningkatkan score nilai anggota dalam kelompok.

Sedangkan Hite (1996) mengamati tentang keunggulan pencapaian aktual dari keberhasilan pengimplementasian metode pembelajaran kooperatif.Hite membandingkan metode pembelajaran secara kelompok dengan yang tidak menggunakan metode pembelajaran individual hasilnya menyimpulkan terdapat peningkatan daya ingat mahasiswa yang belajar secara kelompok dalam menyelesaikan ujian akhir dibanding mahasiswa mahasiswa yang belajar secara individual.Demikian juga dari hasil penelitian Istianingrum dan Sukanti (2012) yang menyatakan bahwa implementasi model pembelajaran kooperatif tipe Numbered Heads Together dapat meningkatkan Aktivitas Belajar Manajemen keuangan dalam Kompetensi Keahlian Manajemen keuangan pada siswa.

\section{Rancangan pengembangan model pembelajaran kooperatif}

Berdasarkan analisis yang telah dilakukan peneliti atas model pembelajaran kooperatif yang sudah dilakukan dan model pembelajaran yang diharapkan kedepan maka
JURNAL NIAGAWAN Vol 6 No 2 Oktober 2017 peneliti akan membuat rancangan pengembangan model pembelajaran kooperatif untuk mata kuliah manajemen keuangan. Pengembangan model pembelajaran kooperatif ini didasari oleh model pembelajaran Student Teams Achievement Division (STAD).

STAD dikembangkan oleh Robert Slavindan teman-teman di Universitas John Hopkin, merupakan pendekatan Cooperatif Learning yang paling sederhana.STAD mengacu pada belajar kelompok, menyajikan informasi akademik baru pada siswa setiap minggu dengan menggunakan presentasi verbal dan teks. Adapun pengambangan model pembelajaran yang dilakukan untuk mata kuliah manajemen keuangan yang selama ini dilakukan adalah pada bagian - bagian berikut :

1. Dalam pembahasan materi kuliah sebaiknya dilakukan secara diskusi kelompok dengan tujuan untuk memberi pemahaman

2. Kelompok terdiri dari $3-5$ orang mahasiswa yang mana pemilihan kelompoknya oleh dosen bersama dengan mahasiswa dan bersifat heterogen.

3. Setiap kelompok atau mahasiswa yang berhasil menjawab/ menyelesaikan tugas dengan benar dan tepat waktu diberi hadiah oleh dosen dan otomatis menambah nilai kelompok maupun individu.

\section{SIMPULAN DAN SARAN}

\section{Kesimpulan}

Berdasarkan hasil penelitian dan analisis hasil penelitian maka dapat peneliti simpulkan bahwa;

1. Model Pembelajaran Manajemen keuangan yang dilakukan dosen pada konsepnya sudah menggunakan model pembelajaran kooperatif.

2. Model Pembelajaran kooperatif yang diterapkan masih belum effektif terlihat dari hasil evaluasi mahasiswa yang masih rendah

3. Perlu adanya pengembangan model pembelajaran kooperatif yang sudah diterapkan pada bagian - bagian ; pembentukan kelompok diskusi, pemberian tugas dan kuis disetiap materi, pemberitahuan/pengumuman atas hasil tugas dan kuis serta memberikan hadiah bagi yang menjawab dengan benar dan tepat waktu, serta adanya penggunaaan lembar kegiatan mahasiswa. 
4. Rancangan Pengembangan model pembelajaran yang dirancang peneliti menggunakan pengembangan pada model pembelajaran Student Teams Achievement Division (STAD).

\section{Saran}

Dari hasil penelitian ini maka peneliti menyarankan agar dapat diketahui apakah pengembangan model pembelajaran ini effektif atau tidak sebaiknya ;

1. Setiap dosen dapat memahami kondisi setiap kelas sebelum menggunakan model pembelajaran dalam penyampaian materi ajar.

2. Perlu adanya implementasi atau penerapan pengembangan model pembelajaran ini pada mata kuliah manajemen keuangan.

3. Perlu adanya sosialisasi model pembelajaran yang baru dikembangkan ini, kepada semua dosen manajemen keuangan yang ada di perguruan tinggi khususnya di Universitas Negeri Medan

\section{REFERENSI}

Abdurrahman, M., \& Totok, B. 2000.Memahami dan menangani siswa dengan problema dalam belajar: Pedoman guru, Jakarta : Proyek peningkatan mutu SLTP Direktoratpendidikan menengah umum, Direktorat pendidikan dasar dan menengah,Departemen Pendidikan Nasional.

Anita Lie. 2005. Cooperative Learning Mempraktekkan Cooperative Learning di ruang kelas.Jakarta : Grasindo.

Cottell, P., and B. Millis.(1993). Cooperative learning structures in the instruction of accounting.Issues in Accounting Education, 40-59.

Hite, P. (1996). An experiment study of the effectiveness of group exams in an individual income tax class. Issues in AccountingEducation, 61-75.

Istiningrum dan Sukanti (2012).Implementasi Model Pembelajaran Kooperatif Tipe NumberedbHeads Together (Nht) Untuk Meningkatkan Aktivitas BelajarManajemen keuangan Pada Siswa Kelas X Ak 2 Smk Ypkk 2 SlemanTahun Pelajaran 2011/2012, Jurnal Pendidikan Manajemen keuangan Indonesia, Vol. X, No. 2, Tahun 2012 Halaman $64-79$
JURNAL NIAGAWAN Vol 6 No 2 Oktober 2017

Inung Pratiwidan Ani Widayati (2012)Pembelajaran Manajemen keuangan Melalui Reciprocal Teaching Model Untuk Meningkatkan Penguasaan Konsep Dan KemandirianBelajar Dalam Materi Mengelola Administrasi Surat BerhargaJangka Pendek Siswa Kelas X Manajemen keuangan 1 Smk Negeri 7Yogyakarta Tahun Pelajaran 2011/2012,Jurnal Pendidikan Manajemen keuangan Indonesia, Vol. X, No. 2, Tahun 2012 Halaman 133 - 152

M. A. Hertiavi , H. Langlang, S. Khanafiyah (2010) Penerapan Model Pembelajaran Kooperatif Tipe Jigsaw Untuk Peningkatan Kemampuan Pemecahan Masalah Siswa Smp Jurnal Pendidikan Fisika Indonesia 6 (2010) 53-57

Junaidi (2009),Pembelajaran Kooperatif pada Mata Kuliah Manajemen keuangan Pengantar: Suatu Eksperimen Lapangan, JURNAL MANAJEMEN KEUANGAN DAN KEUANGAN, VOL. 11, NO.2, NOVEMEBR 2009: 53-64

Lancaster, Kathryn A.S. and Carolyn A. Strand.2001. Using the Team Learning Model in Managerial Accounting Class: An Experiment in Cooperative Learning.Issues inAccounting Education.November Vol. 16, No. 4. p. 549-567.

Lindquist, T. and R. Abraham. (1996). Whitepeak corporation: A case analysis of a Jigsaw II application of cooperative learning. AccountingEducation: A Journal of Theory, Practiceand Research, 113-125.

Oemar Hamalik.(2011). Proses Belajar Mengajar. Jakarta: Bumi Aksara

Peek, L., Winking, C., and G. Peek. (1995). Cooperative learning activities: Managerial accounting. Issues in Accounting Education, 111-125.

Potthast, Margaret J., 1999. Outcomes of Using Small-Group Cooperative Learning Experiences in Introductory Statistics Courses.College Student Journal. March Vol. 22,Issue 1

Slavin, R. (1995). Coopertive learning: Theory, Research and Practice.2nd ed. Needham

Sofyan Syafri Harahap. (2004) "Teori Manajemen keuangan”.Jakarta: Rajawali Pers. 
Suwardjono.(1991). Perilaku Belajar di

perguruan Tinggi.Jurnal Manajemen keuangan.Maret.Yogyakarta.STIE YKPN.

Suwardjono.(1999). Memahamkan Pengetahuan Manajemen keuangan di Tingkat Pengantar.JurnalEkonomi dan Bisnis Indonesia.Vol.14, No.1， 1999.71-78. Yogyakarta.

Trianto.2007. Model-Model Pembelajaran Inovatif Berorientasi Konstruktivisme. Jakarta: Prestasi Pustaka

Wina Sanjaya.(2010). Strategi Pembelajaran Berorientasi Standar Proses Pendidikan.Jakarta: Prenada Media Grup 